\title{
Opportunities and challenges of social media in supply chain management: A study in the South African FMCG retail industry
}

\begin{tabular}{|c|c|}
\hline \multicolumn{2}{|c|}{$\begin{array}{l}\text { Authors: } \\
\text { Furaha Tungande }{ }^{1} \\
\text { Arno Meyer }^{1} \\
\text { Wesley Niemann }\end{array}$} \\
\hline \multicolumn{2}{|c|}{$\begin{array}{l}\text { Affiliations: } \\
\text { }{ }^{1} \text { Department of Business } \\
\text { Management, Faculty of } \\
\text { Economic and Management } \\
\text { Sciences, University of } \\
\text { Pretoria, Hatfield, } \\
\text { South Africa }\end{array}$} \\
\hline \multicolumn{2}{|c|}{$\begin{array}{l}\text { Corresponding author: } \\
\text { Arno Meyer, } \\
\text { arnom@richfield.ac.za }\end{array}$} \\
\hline \multicolumn{2}{|c|}{$\begin{array}{l}\text { Dates: } \\
\text { Received: } 21 \text { Apr. } 2020 \\
\text { Accepted: } 10 \text { Oct. } 2020 \\
\text { Published: } 18 \text { Dec. } 2020\end{array}$} \\
\hline \multicolumn{2}{|c|}{$\begin{array}{l}\text { How to cite this article: } \\
\text { Tungande, F., Meyer, A. \& } \\
\text { Niemann, W., 2020, } \\
\text { 'Opportunities and } \\
\text { challenges of social media } \\
\text { in supply chain management: } \\
\text { A study in the South African } \\
\text { FMCG retail industry', Acta } \\
\text { Commercii 20(1), a864. } \\
\text { https://doi.org/10.4102/ } \\
\text { ac.v20i1.864 }\end{array}$} \\
\hline \multicolumn{2}{|c|}{$\begin{array}{l}\text { Copyright: } \\
\text { (C) 2020. The Authors. } \\
\text { Licensee: AOSIS. This work } \\
\text { is licensed under the } \\
\text { Creative Commons } \\
\text { Attribution License. }\end{array}$} \\
\hline \multicolumn{2}{|l|}{ Read online: } \\
\hline 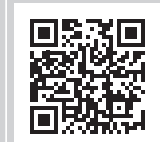 & $\begin{array}{l}\text { Scan this QR } \\
\text { code with your } \\
\text { smart phone or } \\
\text { mobile device } \\
\text { to read online. }\end{array}$ \\
\hline
\end{tabular}

Orientation: Social media is often described a double-edged sword, yielding opportunities and challenges. It brings organisations closer to their customers, and when executed properly it can help drive business and provide a significant return on investment.

Research purpose: To explore the opportunities and challenges that social media has created in SCM in the South African FMCG retail industry.

Motivation for the study: Limited research has been conducted on the innate link between supply chain management (SCM) and social media, especially within the context of the fastmoving consumer goods (FMCG) retail industry and within a developing country context such as South Africa.

Research design, approach and method: A generic qualitative research approach was adopted. Semi-structured interviews were conducted with 12 top and middle managers from the South African FMCG retail industry. Thematic analysis was used to analyse data. This was done in sequential phases, namely by data familiarisation, generating codes, identifying themes, constructing thematic networks and drawing conclusions from the data.

Main findings: The findings indicate that social media has created faster and more collaborative communication between an organisation's suppliers and their customers. However, it has also empowered consumers and forced FMCG retailers to respond faster to consumer complaints and queries to maintain customer relationships for sustained competitive advantage. The lack of control over content that is shared by customers on organisations' social media platforms is a challenge that organisations experienced. The predominant social media platforms found to be used were WhatsApp, Facebook and Twitter.

Practical/managerial implications: Traditional methods of communicating are changing, and organisations need to adapt to social media as an alternative form of technology customer engagement and relationship management. For managers, if social media is embedded in the supply chain, the supply chain can gather information from a broad base of different sources.

Contribution/value-add: This collective intelligence can be used to uncover evolving trends or for better-informed decision-making, planning and overall collaboration between supply chain partners.

Keywords: supply chain management; social media; FMCG retail industry; opportunities; challenges; generic qualitative research; South Africa.

\section{Introduction}

Steve Jobs, the co-founder of Apple Inc., was quoted saying: 'innovation is the ability to see change as an opportunity and not a threat'. One of the most significant innovations has been information technology (IT) (Ben-Daya, Hassini \& Bahroun 2019:4720). The Internet can be considered as one of the most influential on the evolution of all business processes (Markova \& Petkovska-Mircevska 2013:90; Swan 2017:6). Likewise, there have been many innovations in the supply chain industry with the emergence of IT over the years such as enterprise resource planning (ERP), SAP, Oracle and PeopleSoft, to name a few (Wong \& Ngai 2019:158).

This emergence of IT in supply chain management (SCM) has created both opportunities and challenges for firms to engage, manage and communicate with customers, which have been augmented by social media (Wang, Wang \& Che 2019:280). 
Customer engagement is central to the effective use of social media and likewise customer relationship management (CRM) in SCM (Markova \& PetkovskaMir evska 2013:92). Customer relationship management, underpinned by relationship marketing principles, is an important research domain, which has experienced peaks and troughs of interest, with both success and failure stories on the marketing and technology sides (Payne \& Frow 2005). Similarly, CRM is a key supply chain process that concerns the relationship between the organisation and its customers (Nguyen \& Mutum 2012:404). Organisations, especially organisations operating in the fast-moving consumer goods (FMCG) industry, need to embrace the opportunities presented by social media engagement platforms as FMCG retailers are required to be flexible to be able to cope with technological change, innovation and globalisation, as well as the constantly changing customer demands, needs and expectations (Manders, Caniëls \& Paul 2016:181).

Social media CRM is gaining momentum as the next generation for CRM (Choudhury \& Harrigan 2014:149).

Traditional CRM strategies focussed on management solutions for channels such as corporate web sites, call centres and brick and mortar locations (Agnihotri et al. 2016:172). With social media CRM, these strategies now take into account the instantaneous dynamics of the community-based environment that defines social media, which is an environment in which control of the relationship has shifted to the customer, who has the power to influence others in his or her social network (Zadeh, Zolfagharian \& Hofacker 2019:284).

From an academic perspective, the significance of social media for organisations has been investigated from a multiple-disciplinary perspective. Ngai, Tao and Moon (2015:33) researched social media from and information management perspective; Alavi and Denford (2011:105) researched the efficiency of information sharing in knowledge management. From a human resource management perspective, Poba-Nzaou, Uwizeyemungu and Clarke (2018:1) identified the challenges of adopting social media for organisations. As such, there has been criticism for the lack of research and overall use of social media in SCM (Orji, KusiSarpong \& Gupta 2020:1522; Singh, Shukla \& Mishra 2018:398).

Furthermore, according to the research by Kasemsap (2018:12) as well as Ramanathan, Subramanian and Parrott (2017:105), two-thirds of organisations in the supply chain industry worldwide have done little in terms of social media presence. This is a poor reflection on the industry, considering that with advances of technology such as smartphones, customers are less passive, more empowered and more inclined to use social media for communicating with organisations and their brands (Gunarathne, Rui \& Seidmann 2017:315)
Thus, in line with the above suppositions, a distinctive gap in extant literature that the study investigates is the lack of research on social media in SCM, which is evident in the lack of literature reviews and empirical studies, which provides justification for the purpose of the current study.

The primary aim of this generic qualitative study was to explore the opportunities and challenges social media poses in SCM, with a specific focus on the FMCG retail industry in South Africa. The secondary aim of the study was to identify the landscape of current social media platforms that South African FMCG organisations use to improve both their CRM and SCM. The following research questions guided the study:

- What opportunities has social media created in SCM within the South African FMCG retail industry?

- What are the challenges that social media has created in SCM within the South African FMCG retail industry?

- Which predominant social media platforms are used by FMCG retailers and their customers within South Africa?

The study provides findings on the opportunities and challenges that social media use may offer, specifically for South African FMCG retailers. More definitively, the study's findings motivate the integration of social media practice into the SCM of FMCG retailers and demonstrate how other FMCG organisations that are already using these applications can improve existing social media practices in their SCM. Secondly, the study elucidates the predominant platforms for customer engagement in a South African FMCG retail context. Additionally, the study indicates the social media platforms' potential to be used to monitor organisational responsiveness to engage with customers and improve overall social media CRM. Finally, the study describes the effects of social media engagement between an FMCG retailer and its customers on the customer and the influence of an empowered customer on the retailer.

\section{Literature review}

\section{Overview of the fast-moving consumer goods retail industry}

Mvubu and Naude (2016:274) have described the SCM of organisations as the management of seamless, value-added flows of products, information and funds throughout the supply chain. FMCGs are often products that offer a low profit margin and have high sales volumes such as beverages, packaged food, personal care and household cleaning products (Bala \& Kumar 2011:23). The global FMCG industry is recognised as a leader in SCM practices (Rodrigues 2013:351). Fast-moving consumer goods organisations' primary focus is creating a supply chain that provides for the needs of customers in the most effective and efficient possible manner (Syed \& Siddiqui 2019:9386). Because of the agile nature of FMCG supply chains, flexibility is crucial for meeting customers' demands (Govender et al. 2018:1766). 
Likewise, in South Africa, the FMCG industry represents one of the most important growing economic SCM sectors for gross domestic product (GDP) development (Meyer, Niemann, Uys \& Beetge 2019:3). The FMCG retail industry in South Africa is faced with the challenge of providing high service quality to customers. Service quality is described as the distance between a customer's expectation of how they feel a service should be performed, and their perception of how that service was performed (Gouws \& Motala 2019:1).

The South African FMCG industry has experienced had immense growth in the past 2 years, which examines consumers' online purchasing behaviours, reported that $91 \%$ of South African consumers who have access to the Internet have made a purchase online, with the most significant growth in the fashion industry and online restaurant deliveries and meal kit services (Nielsen 2018). However, the FMCG retail industry has one of the most challenging and complicated supply chain industries to manage not only because of the complexity of its goods and service offerings but also because it is very end-consumer centric (Singh et al. 2018:398).

A way to address the pressures arising in the FMCG industry to remain competitive is to incorporate the use of social media throughout the supply chain as it permits the development and meaningful CRM with current and existing customers (Rapp et al. 2013:547).

\section{Social media platforms}

Social media is a group of Internet-based applications that build on the technical foundations of Web 2.0 and allow the creation and exchange of user-generated content (Whiting \& Williams 2013:133). Social media includes online sources of information that are formed, distributed and used by consumers to inform one another about products, services and brands (Whiting, Williams \& Hair 2019:133). Moreover, social media comprises social networking sites, online communities, video-sharing sites, review sites, dating sites and the virtual game world (Gussenhoven \& Rabinowitz 2014:9). The Internet has boosted the abundant growth of social media in the past decade, with the emergence of social networks such as Twitter, Facebook and Instagram amongst others (Meixner et al. 2013:29).

As social media is vast and ever-changing, how a customer can identify a physical store by its branding must be the same way in which a customer can identify the organisation's online presence and be able to access the right accounts when needed (Kapoor et al. 2018:532). The ability to meet customers' demands in full and on-time is what creates a competitive advantage for FMCG retailers (Vogt, Förster \& Kabst 2014:85). Social media communication strategies offer FMCG retailers a mechanism for improving their agility for customers engagement, smoothing demands and gathering data about customer opinions on goods being provided, at a low cost compared with paid marketing and advertisement campaigns (Kasemsap 2018:1154).

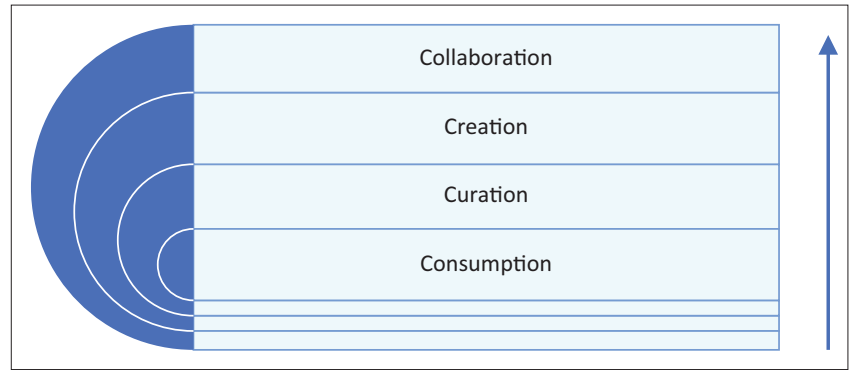

FIGURE 1: Structured engagement.

Diffley and McCole (2019:114) posit that organisations that have little to no social media presence are lagging behind their competitors. Ultimately, social media use has influenced organisations to change how they view and manage their customer relationships, which has required a transformation of traditional approaches to meet the changing demands of customers (Pearson 2015:20). Unlike traditional media, social technologies push towards collaborative relationships with customers rather than mere exposure and impression marketing (Markova \& PetkovskaMircevska 2013:90). Social CRM is based on the four basic building blocks of 'social engagement' (Evans, McKee \& Bratton 2010:15), which are consumption, curation, creation and collaboration. These fundamental blocks lead to and support a ladder-type engagement model with customer collaboration as the end point and desired result (refer to Figure 1).

\section{Supply chain opportunities from social media}

There are several opportunities for organisations to enhance their social media presence and thereby improve their customers' experiences (Kietzmann et al. 2011:242). The empowered customers tend to have an extremely low tolerance for poor service and quality and readily report their problems online (Cui et al. 2018:1). Social media has enabled additional service channels for customers, whereby organisations can offer a more personal touch as opposed to traditional methods of lodging complaints, for example, telephonically or via email (Pearson 2015:21).

The correct adoption of social media CRM within an organisation can have a positive influence on brand loyalty and image (Ismail 2017:129). Social media can be applied within an organisation's operations at a relatively low cost, as there is little to no cost associated with implementation. For example, there is no cost involved in creating a Twitter, Facebook or WhatsApp profile, and organisations acquire the opportunity to create online communities for their customers and communicate actively with their customers through these online communities (Meixner et al. 2013:29).

A study conducted in 2017 on United States (US) social media marketing regarding marketing strategies was undertaken by Ripl. The study collected 371 responses from businesses; when posited with their strategy and variety of choices ranging from organic (i.e. self-posted) social media posts, their own branded website, paid advertisements and other options, the 
results indicated the strong trend to social media as the main method to reach customers as depicted in Figure 2.

Furthermore, the amalgamation of social media in the supply chain can provide organisations with additional insight and data from consumers (O'Leary 2011:122). An example of extrapolating data from social media is McDonald's. McDonald's turned to social media to find out how important all-day breakfast was to its customers. Combing through Twitter, they uncovered more than 334000 tweets from McDonald's fans mentioning all-day breakfasts dating back to 2007. McDonald's then sent personalised tweets to nearly 12000 fans who craved McMuffins at midnight, alerting them of their debut of all-day breakfast. The launch was such a success: All-day breakfast is credited with helping to reverse a 14-quarter decline for the company, as well as a $10 \%$ improvement in positive customer sentiment.

In a follow-up research article by O'Leary (2016:215), it has been suggested that Facebook-like capabilities can be created to help SCM in various ways. Facebook creates the opportunity for gathering information about opinions, building and maintaining relationships, so ultimately trust can be built amongst networks. A social media platform allows an organisation to build enterprise trust and a personal relationship with its customers, who feel closer to an organisation if they can easily access the organisation (O'Leary 2016:215).

Even though it can be argued that it is difficult to place a monetary value on implementing social media practices within an organisation, social media provides organisations with the opportunity to build strong social capital through engagements on online networks. This has great potential to provide intelligence for improving supply chain performance as social capital can also be used as a competitive advantage (Swain \& Cao 2013:4).

At the same time, it is extremely important to justify investments in social media and to assess critically social media's financial value to the organisation if any (Deans 2011:188). Some organisations have gone to the extent of incorporating social media applications in their demand forecasting to derive real demand (Chae 2015:247; Singh et al. 2018:404).

\section{Supply chain challenges of social media}

Social media has also changed how business is conducted and how organisations communicate with their customers (Rapp et al. 2013:548). Customers have become more information-seeking, and their decisions are influenced by what they see about other customers' experiences on social media platforms. These experiences impact the decisions customers will make on their next purchase (Bronner \& de Hoog 2014:51). Social media is evolving and organisations that do not have a social media presence run the risk of being out of touch with their customers (Kietzmann et al. 2011:214).

Social media has also become an important tool for customers to use in making their purchasing decisions, and this is now changing how customers behave and perceive organisations (Gunarathne et al. 2017:315). Everyone on social media platforms is considered a publisher (Meixner et al. 2013:28), and research has shown that information that is shared on review sites, on individual's pages, blogs, Facebook and Twitter influences consumer decisions (Asur \& Huberman 2010:2). As a result, organisations have little or no control over the narrative that is shared on these various sites and social media platforms (Gunarathne, Rui \& Seidmann et al. 2018:491; Kietzmann et al. 2011:242).

The choice of the appropriate social media platform to operate on may be challenging for organisations but is crucial (Campie 2015:51). Consequently, an organisation should not choose a social media platform for the simple purpose of being active online or because a competitor is on that platform. Rather, the social media strategy should align with the organisation's strategies and objectives (Kaplan \& Haenlein 2010:65). Different social media platforms appeal to different segments of the market. An organisation may therefore be faced with the challenge of having to manage multiple social media accounts to cater to the different market segments (Kaplan \& Haenlein 2010).

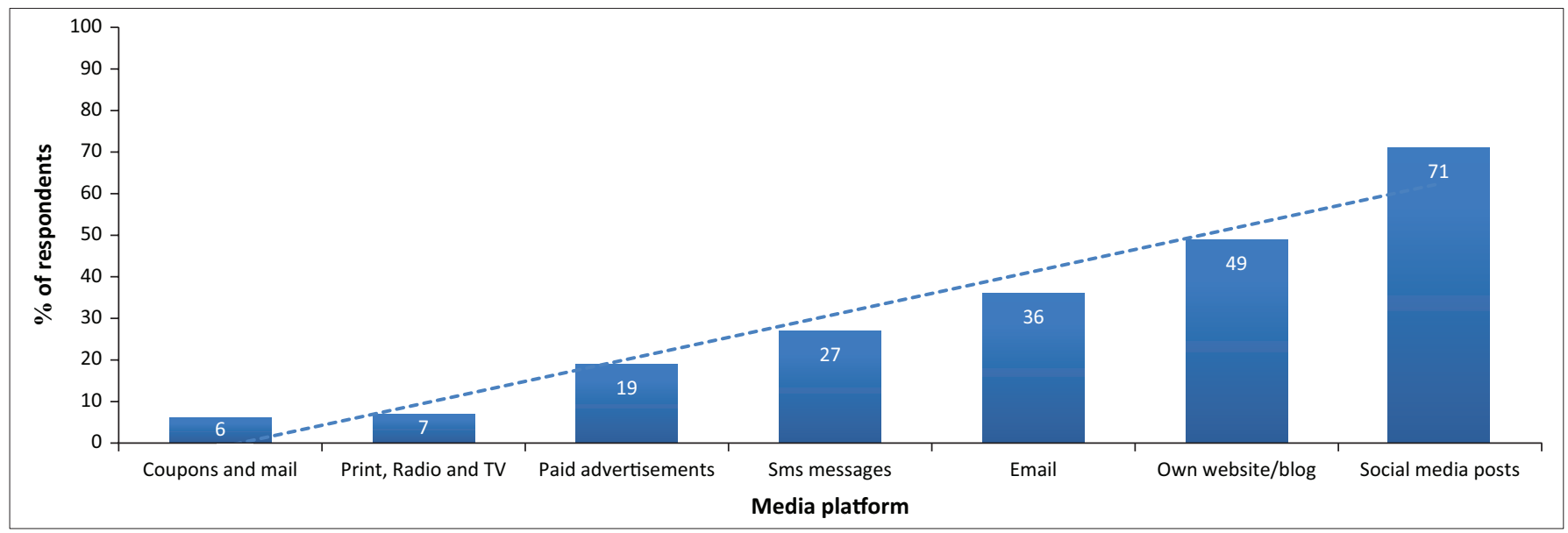

FIGURE 2: Channels used for customer engagement. 
Furthermore, the organisation must choose between creating an online application and making use of an existing social media platform (Kaplan \& Haenlein 2010:65). Social media creates open access between the customer and the organisation. Whilst this may be the aim of creating social media platforms, and it may be done with a positive intent, it can be to the detriment of the organisation if it cannot respond adequately to customers (Bharucha 2018:75). Does the question become how much access should the organisation allow? Information can be volatile on social media, and from a public relations standpoint, there need to be limitations and careful strategies created as a line of defence for the organisation if there is an unfavourable online incident (Valentini 2015:171).

It is challenging to remain interesting and impactful on social media because of how fast information is consumed by users. Organisations are faced with the challenge of having to stay relevant and up to date with users to appeal to them (Kaplan \& Haenlein 2010:66). The key is, to be honest, with what it is that the organisation can offer to customers through the interaction that they display (Bronner \& De Hoog 2014:52).

Social media can be seen as a theatre stage, and organisations need to remain authentic with their customers at all times (Kaplan \& Haenlein 2010:67).

Moreover, organisations may be in control of what they post, but how posts and campaigns are interpreted is based on users and customers. At times an organisation cannot control the negativity that customers have shared online. Unfavourable reviews, for example, are displayed in the same section as favourable reviews.

Moreover, consumers have been described as having different types of power that affect how organisations will operate and serve them (Flynn et al. 2008:170). Expert power is described as the power that a customer has based on expertise or knowledge, whilst coercive power is described as the ability of the consumer to provide criticisms that are detrimental to the organisation (Flynn et al. 2008:171).

The above-mentioned powers are brought to light at a faster rate and experienced more intensely because of social media; consumers exercise these two types of power at any given moment with a large audience that can be easily reached through social media (Flynn et al. 2008:170). Quick response is a key concept not only in the supply chain but also in social media. Organisations must take into account how long it takes to respond to customers online, as the longer it takes the more difficult it becomes to manage the narrative that is being shared online (Ramanathan et al. 2017:3).

If something untoward happens, this almost makes organisations powerless, as at that time the power lies completely in the hands of that consumer (Shirky 2011:2). The possible reputational damage that can be experienced because of the dissatisfaction of the consumer does not solely affect the organisation at hand; it may at times extend to supply chain partners as well. Reputational damage can be immense and can take a long time to remedy and repair within the organisation and with supply chain partners involved (Canada 2019:12).

\section{Methodology Research design}

The study was guided by generic qualitative research design. Generic qualitative research seeks to understand a variety of perspectives and the views of those people who are involved with the study (Bellamy et al. 2016:672). This research approach draws concepts and insights from data as opposed to using data to test a preconceived hypothesis (Taylor, Bogdan \& DeVault 2015:7). The generic qualitative approach was therefore used as this was the most appropriate research technique for this study. By using generic qualitative research, the researcher already has a body of pre-knowledge about the topic but aims to gain more understanding of the perspectives of participants to add to the existing body of knowledge (Percy, Kostere \& Kostere 2015:78). This study aimed to investigate the opportunities and challenges of social media in supply chains in the FMCG retail industry. Semi-structured interviews were conducted with senior managers in the FMCG industry.

\section{Study population and sampling strategy}

A total of 12 interviews were conducted with participants from 12 different FMCG retailers. The study employed homogenous sampling. This was used as the study investigated similar or identical characteristics within the FMCG retail industry, and homogenous sampling of the units (retailers) ensured the chosen sample members had similar or identical characteristics (Elmusharaf 2012:15). It allowed for deliberate selection of FMCG retailers to be studied because these organisations are 'information-rich' and offered the best opportunity to inform and add to the expected outcomes (Guest, Bunce \& Johnson 2006:16). Organisations had to be located in South Africa, operate in the FMCG retail industry and to have been in business for over 10 years as this would reflect an organisation that has experienced changes in the industry.

Similarly, the most suitable and knowledgeable individuals in these organisations were targeted in an effort to get deep access to the organisations. Participants had to be in senior or middle management SCM position and have at least 3 years of experience in the industry. In studies consisting of homogenous participants, data saturation can be achieved within the first 6-12 interviews (Mason 2010:78). Data saturation was achieved after 10 interviews as no new information emerged after the 10th interview; two additional interviews were conducted before data collection was terminated. Table 1 shows a profile of the study participants. 
TABLE 1: A profile of the study participants.

\begin{tabular}{|c|c|c|c|c|c|}
\hline Participant & Position & Firm & Gender & Years employed & Length of interview in min \\
\hline P1 & Logistics Manager & F1 & Male & 3 & 47.33 \\
\hline P2 & Customer Facing Supply Chain and Market Service Strategy Lead & F2 & Female & 12 & 38.17 \\
\hline P3 & Customer Team Logistics Leader & F3 & Male & 12 & 35.46 \\
\hline P4 & Africa Zone Compliance Manager & F4 & Male & 5 & 31.27 \\
\hline P5 & Supply Chain Manager & F5 & Male & 18 & 64.04 \\
\hline P6 & Supply Chain Manager & F6 & Male & 5 & 74.00 \\
\hline P7 & Category planning manager & F7 & Male & 3 & 40.24 \\
\hline P8 & Logistics Manager & F8 & Male & 3 & 39.43 \\
\hline P9 & Operational Planning Manager & F9 & Male & 7 & 24.00 \\
\hline P10 & Supply Chain Director & F10 & Male & 3 & 53.08 \\
\hline P11 & Manager: Special Projects Supply Chain & F11 & Female & 5 & 31.59 \\
\hline P12 & Supply Chain Manager & F12 & Female & 3 & 66.00 \\
\hline
\end{tabular}

Note: Average interview length: $45 \mathrm{~min}$.

\section{Data collection}

The study explored a phenomenon that required the personal perspectives and experiences of participants and therefore made use of semi-structured interviews. These interviews provided an opportunity to generate rich data and gain insight into perceptions (Newton 2010:2). The semi-structured interviews were guided by a discussion guide with questions that allowed the interviewers to gain as much information as possible. Seven interviews were conducted at the organisations' headquarters, and five interviews were conducted telephonically. A discussion guide was developed with the study's research questions as a basis and underwent a pretest with one organisation. No significant changes were required, and data collection continued.

Interviews began with a brief description of the study followed by requesting participants to sign an informed consent form. All were recorded and the transcriptions outsourced to a professional transcription service.

These were checked to ensure the accuracy of information by reviewing each transcription whilst listening to the corresponding recording. The average length of interviews was $45 \mathrm{~min}$ as shown in Table 1.

\section{Data analysis}

This study employed a thematic analysis of data as this approach provides an in-depth description and interpretation of each participant's perspectives (Vaismoradi et al. 2016:101). The thematic analysis was done in five phases, namely data familiarisation, generating initial codes, identifying themes, constructing thematic networks and integration and interpretation (Robinson 2014:25). This research utilised a computer-assisted qualitative data-analysing software (CAQDAS) package called Atlas.ti (version 8) to efficiently analyse the large amounts of data from the interviews. Atlas. $\mathrm{ti}$ is specifically developed to generate and manage codes as well as identify the relationship between codes and themes. The researchers became familiar with the data by reading the transcripts whilst listening to the recordings. During data analysis, inductive codes were created from the data and merged with deductive codes found (Braun \& Clarke 2012:57;
Creswell 2012:243). These codes were then analysed and combined into a set of overarching themes according to their relevance to the study's overall research questions (Braun \& Clarke 2012:57; Creswell 2012:243). These themes were then analysed against the transcriptions to ensure that they covered all relevant patterns (Braun \& Clarke 2012:63-65). This process was repeated where it was deemed necessary.

\section{Trustworthiness}

Four trustworthiness criteria, namely credibility, transferability, dependability and confirmability, were employed to ensure the trustworthiness of this qualitative research study (Polit \& Beck 2012:583). Credibility relates to how well the findings in the study reflect the genuine perspectives and experiences of the participants (Lietz \& Zayas 2010:191). To obtain credibility, the researchers firstly ensured compliance with the ethical requirements of both confidentiality and voluntary participation from each participant. Secondly, the researchers employed trusted methods such as purposive sampling and thematic analysis of the data collected to ensure accuracy (Polit \& Beck 2012:584). Transferability was also ensured by using an existing methodology that can be replicated for alternate situations, contexts, practices or future research (Lietz \& Zayas 2010:195; Polit \& Beck 2012:585).

Dependability was used as explained by Lietz and Zayas (2010:195) as the degree to which a research study's procedures are documented, allowing someone outside the study to follow and critically evaluate the research process. Confirmability was used; this is concerned with objectivity, and steps were taken to ensure that the responses of participants were not influenced by the preferences or biases of the researcher (Polit \& Beck 2012:585; Shenton 2004:72). Open-ended questions were used in the discussion guide to permit the participants to navigate through the questions by giving their experiences in their way (Milne \& Oberle 2005:415). Also, transcripts of the interview recordings were confirmed by reading the interview transcripts at least twice whilst listening to the recordings (Milne \& Oberle 2005:416). A detailed explanation of the context of the research study as well as a discussion guide and interview protocol are provided. 


\section{Ethical considerations}

The ethical permission for the study was obtained from the Research Ethics Committee, Department of Business Management, University of Pretoria. All participants provided voluntary consent by reading and signing an informed consent form before the interviews commenced. The researchers emphasised the anonymity and confidentiality of information provided and findings of the study and reminded participants that they might withdraw from answering any question that they did not feel comfortable answering. Pseudonyms were assigned to each participant and firm to ensure further anonymity and confidentiality in the study.

\section{Findings}

Three themes were identified and extracted from the collected data. The related sub-themes are discussed under each main theme.

\section{Theme 1: Supply chain opportunities social media has created}

The first research question of this study related to opportunities social media has created in SCM within the South African FMCG industry. The sub-themes that were identified are Internal Communication, External Communication and CRM (refer to Figure 3).

\section{Internal communication}

All 12 participants stated that social media has created opportunities and benefits for their supply chain. Moreover, social media has created a way for organisations to communicate faster and more effectively with supply chain partners. The following extracts pertain to the social media application:

'So, when it comes to social media, we, have our own platform, I would rather liken it to Instagram if you are internal. It is local but to everyone in the organisation only. So, it is not only for South Africa, it is everyone linked to this organisation in its entirety.' (P12, female, Supply Chain Manager)

'We have our own internal kind of social media platform, called Ruby Report, where you can see top management being promoted; what brands have launched; what other companies in other countries have done. So, it's obviously more internal use

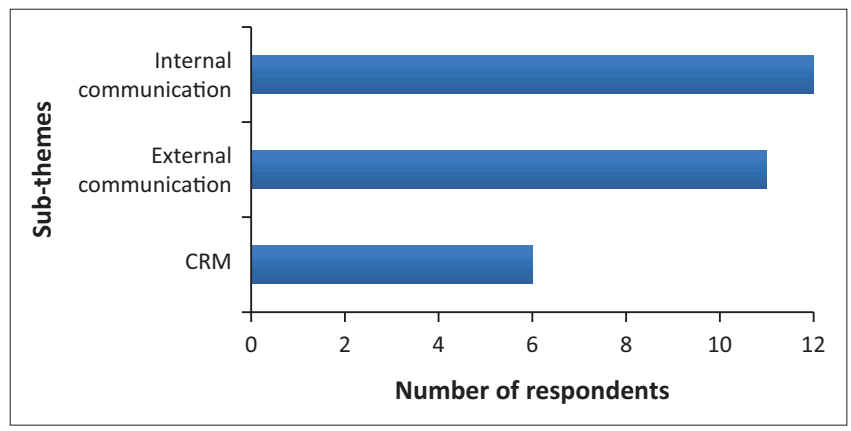

CRM, customer relationship management.

FIGURE 3: Theme 1 findings. for people to keep aware of what's happening. Things that you wouldn't mind the rest of the world seeing, but the rest of the world doesn't need to know.' (P6, male, Supply Chain Manager)

The findings of the study support the research of Rapp et al. (2013) state that social media has changed how business is conducted. The above-mentioned extracts also support the findings of Meixner et al. (2013) who state that social media can be applied within an organisation's operations.

\section{External communication}

Eleven respondents indicated that social media was key for external communication with customers and for marketing purposes, whilst organisations encourage communication with their customers through their social media platform and have the ability to reach more customers with the use of social media. The following quotes illustrate this:

'Definitely more opportunities can be created with the use of social media because you can reach people outside of your own geography and you can create benchmarking opportunities and experiences across channels and you can leverage off mature markets and developed markets ...' (P10, male, Supply Chain Director)

'A key thing is things like really getting the communication out on adverts, Black Friday if you have Black Friday deals coming on where there will be a banner on a News 24 programme or on Facebook or on Instagram.' (P6, Male, Supply Chain Manager)

Ismail (2017:129) states that social media platforms facilitate open communication between organisations and their customers. The findings are in agreement with the extant literature; however, a framework for external communication is yet to be successfully created within South African FMCG retailers.

\section{Customer service}

Six respondents indicated that they were currently not using social media for customer service purposes and still relied on traditional methods of customer service such as customer care and service call centres as well as emails. This is indicated with the following quotes:

'Not much, generally customer service is telephonic or via email. I would say customer relationships and marketing activities is more in the traditional social media space.' (P2, Female, Customer Facing Supply Chain \& Market Service Strategy Lead).

'Those kinds of platforms definitely need a custodian who is there if there is a query or a comment, it needs to be responded to almost immediately, which is not always possible.' (P12, female, Supply Chain Manager)

Diffley and McCole (2019:114) state that organisations that have little to no social media presence are lagging behind their competitors. The study revealed that South African FMCG retailers are still using traditional CRM approaches in terms of using social media for customer service purposes. 


\section{Theme 2: Supply chain challenges that social media has created}

The second theme of this study relates to the challenges that social media has created in SCM within the South African FMCG retail industry. The sub-themes identified are empowered customers, the lack of control over the information that is shared on social media and fake news. (refer to Figure 4)

\section{The empowered customer}

Nine respondents have mentioned that customers are more empowered because of social media. The voice of the customer is broadcast over a platform where many other customers can see their sentiments albeit positive or negative. The following quotes illustrate examples of the empowered customer:

'The power that lies with the end consumer nowadays, and the effect that it can have on your brand, is overwhelming, so I think that's changed the engagement with the final consumer. Social media has given them more power and the power to affect your brand.' (P1, male, Logistics Manager)

'If you have a Facebook page, you need to be willing to accept and expect bad feedback. People normally rather complain than compliment. So, you need to monitor that. You can't allow these types of questions to remain unanswered.' (P7, male, Category Planning Manager)

If something untoward happens, this almost makes organisations powerless, as at that time the power lies completely in the hands of that consumer (Shirky 2011:2). This sentiment is supported by the findings as FMCG retailers are struggling to proactively meet the changing customer demands and following trends on social media.

\section{Lack of control}

Six of the respondents stated that the nature of social media makes it difficult to control the information that is shared online; the information shared is displayed in full view of other customers and has the potential to influence customers positivity or negatively. The following quote illustrates this:

'Those kinds of platforms definitely need a custodian who is actively there if there is a query or a comment, it needs to be

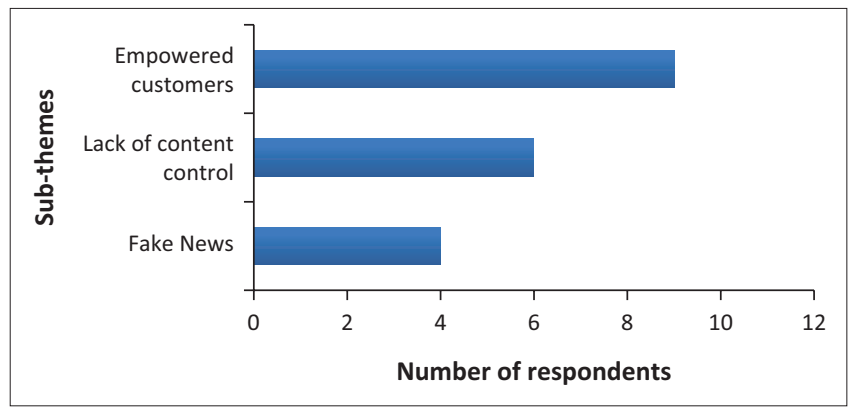

FIGURE 4: Theme 2 findings. responded to almost immediately.' (P12, female, Supply Chain Manager)

'Yes, very much so. The bulk or a good percentage of our customer complaints come from social media.' (P4, male, Africa zone compliance manager)

The findings support the research by Valentini (2015:171), who states that information can be volatile on social media, and from a public relations standpoint, there need to be limitations and careful strategies created as a line of defence for the organisation if there is an unfavourable online incident.

\section{Fake news}

Four respondents expressed that they had experienced some form of negativity on their social media platforms that were because of disgruntled customers. The following quote describes the nature of the negatively that occurred:

'Generally, media backlash due to exaggeration is due to fake news. We've had a lot of damaging fake news, in the last, let's say five to 10 years.' (P2, female, Customer Facing Supply Chain \& Market Service Strategy Lead)

'Twitter has dragged the company a couple number of times through the mud, we launch a campaign or something like that and it's not well received by the community at large then it starts to trend on social media and then it's a hashtag this or something similar and it does affect the business and we take it very seriously. We take every case very seriously.' (P4, male, Africa Zone Compliance Manager)

The findings support the research of Canada (2019:12), who states that fake news spread on social media has the potential to cause reputational damage, which can be immense and can take a long time to remedy and repair within the organisation and with supply chain partners involved.

\section{Predominant social media platforms used}

The third research question of this study relates to mainstream social media platforms that are predominantly used by FMCG retailers to communicate with their suppliers and customers. (refer to Figure 5)

\section{WhatsApp}

All 12 respondents indicated that WhatsApp is used within their organisations; however, the findings show that they only use it for either to communicate internally amongst employees or with suppliers. This is illustrated with the following quotes:

'We have a couple of WhatsApp groups with our suppliers. So, instead of sending an email and the guy getting it in the afternoon then you rather send the WhatsApp on the group and they attend to it quite fast.' (P8, male, Logistics Manager)

'We have WhatsApp groups for our distribution managers. These guys post on the WhatsApp group what's their warehouse utilisation like; how many vehicles did they dispatch; did they dispatch them on time; what was the utilisation of those vehicles; were there any staff issues. So just like a short update in the 


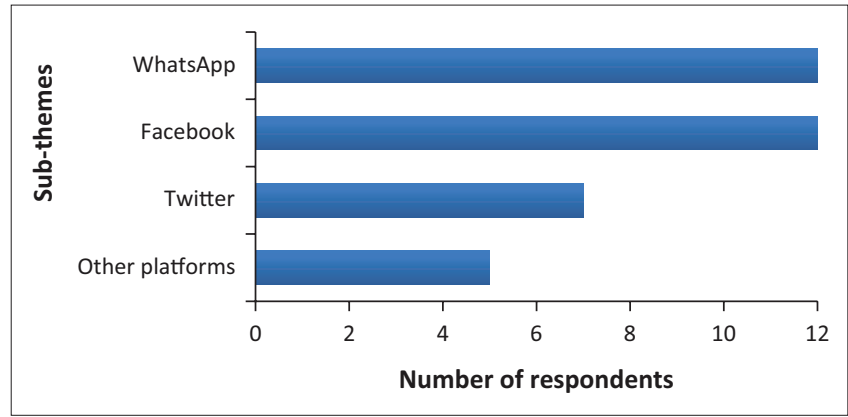

FIGURE 5: Theme 3 findings.

morning and that's sent to basically all the management and above levels within the supply chain.' (P11, female, Manager Special Projects Supply Chain)

'The WhatsApp groups definitely improved collaboration with our suppliers.' (P12, female, supply chain manager)

The findings support the research by Pozin, Nawi, Mydin, Riazi \& Imran 2019), who state that the use of WhatsApp overcomes the communication barriers between supply chain partners and provides real-time feedback, which in turn results in faster communication and decision-making. This finding presents a latent research question on how WhatsApp can be utilised for customer engagement.

\section{Facebook}

All respondents reported the use of Facebook to communicate with their customers as well as receive feedback from customers. This is illustrated by the following quotes:

'We have acustomer services team. We had a consumer complaints hotline, but more often people use Facebook and don't go there, so we've been monitoring; you actually have businesses that monitor brand mentions and stuff, and they would alert us to, "Hold on, here's the problem" and then you can react to that.' (P5, male, Supply Chain Manager)

'I think Facebook because the the older generation and youth use Facebook more or less. More youth use Instagram than the old people. So we are on Facebook, we have more customers to get to than Instagram.' (P8, male, Logistics Manager)

'Primarily they use Facebook. The reason why is you want to have people engaging with other people on there. You want people to talk about their experiences.' (P6, male, Supply Chain Manager)

The findings support the research of Triantafillidou and Siomkos (2018:164), who state that Facebook is the most engaging platform for customer engagement and is best suited to build, invest in and maintain relationships.

\section{Twitter}

Six of the respondents use Twitter for customer promotion purposes, as illustrated by the following quotes:

'So that goes with hits. I think that's the term that we use. So, the more hits you get on a particular platform, Twitter is I'd say is probably the biggest for us, the more energies and resources we put.' (P4, male, Africa Zone Compliance Manager)
'We use Twitter, it's positive but we are cautiously optimistic ...' (P10, male, supply chain director)

There is potential for Twitter to be used more by FMCG retailers in South Africa as the majority of respondents currently do not use it for advertising purposes, and this may be because of a possible lack of knowledge they have of Twitter, as indicated by the following quote:

'So there is a big future with Twitter, I suppose it's for the experts to tell us how would be the best way to deploy ...' (P4, male, Africa zone compliance manager)

According to Chae (2015:256), Twitter can generate sales for organisations. If a campaign is effectively promoted on social media the realised profits that can be substantial. The findings are in line with the extant literature; however, FMCG retailers need to be educated on how Twitter can be used as a strategic tool to extract data and predict demand more than just merely using it for promotions as is the current case.

\section{Other platforms}

Five of the respondents indicated that in conjunction with the above-mentioned social media platforms, they make use of enterprise social media platforms such as Microsoft Teams, Workplace and Skype for business to share confidential information as well as communicate internally as employees in a faster manner as opposed to sending emails or scheduling meetings. This is illustrated by the following quote:

'Microsoft Teams gives you the opportunity to share all your files directly, so everybody is working on the same things whereas in the past it was very disjointed. If someone left or somebody was on leave and all the information was on the PC, [personal computer] we would struggle. Now with Microsoft Teams, you put everything there and everybody works on it. It's accessible.' (P3, male, Customer Team Logistics Leader)

"We do a firm "Facebook" called Workplace, that we use extensively ...' (P2, female, customer facing supply chain and market service strategy lead)

\section{Conclusion Summary of findings}

This study aimed to explore the opportunities and challenges of social media in SCM within FMCG retailers in South Africa. The first research question of this study explored the opportunities social media has created in SCM within the South African FMCG retail industry. The study confirms that there are opportunities that organisations have identified, mainly the ability to communicate more effectively internally and create better external communication with customers. The second research question investigated the challenges that social media has created in SCM within the South African FMCG retailers. Empowered consumers can share their sentiments any given moment with a large audience that can be easily reached through social media, and respondents confirmed that customers are more prone to complain or 
leave negative comments than to compliment organisations. The lack of control over content that is shared by customers on organisations' social media platforms is a challenge that most respondents experienced. Fake news affected some organisations, but it is a factor that all organisations that use social media are potentially exposed to.

The third research question examined mainstream social media platforms that are predominantly used by FMCG retailers and their customers within South Africa. All respondents in the study used WhatsApp and Facebook. The interesting finding is that WhatsApp is only used for suppliers and Facebook is only used for customers. The findings suggest that Twitter is used by FMCG retailers mainly for promotional purposes.

\section{Theoretical implications}

The findings of this study contribute to the academic body of knowledge by identifying the use of social media in SCM as a form of new technology that may affect the supply chains of the future. Organisations are aware of the impact that social media has on the supply chain, and organisations that seek to be market leaders in the field of SCM can leverage off the use of social media to differentiate themselves and allow organisations and brands to stand out. The implication for the academic body of knowledge is that the study's findings motivate the integration of social media practice into the SCM of FMCG retailers that do not currently use social media and demonstrate how other FMCG organisations are already using this application, although there is also an opportunity to improve existing social media practices in their SCM.

\section{Managerial recommendations}

The study revealed that social media platforms are currently being under-utilised by managers and organisations to engage with their suppliers and, more significantly, their customers. There is potential for organisations to use these social media platforms to gather data, as seen in some organisations that have gone to the extent of incorporating social media applications in their demand forecasting to derive real demand. As one participant mentioned, the need for experts to educate organisations on the true power of social media might be the catalyst for FMCG retailers to leverage the full benefits of social media platforms.

Secondly, managers should not see social media as a part of their technology strategy that is not worth investing in. Specifically, for supply chain managers, the study provides insights into how social media as a means of technology is being used in other organisations, as well as the potential importance that social media will have within SCM in the future. As technology grows and evolves, social media can provide organisations with alternative ways of effective communication with customers as well as cost-effectively create customer services solutions.

\section{Limitations}

The small sample size used in this qualitative study limits the generalisability of its findings. Moreover, because of the qualitative nature of the study, only one participant from one department from each organisation was represented. Therefore, it would be valuable for future research to be conducted from a quantitative methodology to compare the research findings. Future research could focus on different sectors in the FMCG industry or other industries such as manufacturing or third-party logistics industries, which also have strong customer interaction.

\section{Acknowledgements Competing interests}

The authors declare that they have no financial or personal relationships that may have inappropriately influenced them in writing this article.

\section{Authors' contributions}

A.M. and W.N. prepared the article. F.T. collected data of the research as part of their MPhil degree. A.M. and W.N. acted as the supervisors of the research and prepared the manuscript.

\section{Funding information}

This research received no specific grant from any funding agency in the public, commercial or not-for-profit sectors.

\section{Data availability statement}

Data can be shared upon request. However, participants and organisations will remain confidential.

\section{Disclaimer}

The views and opinions expressed in this article are those of the authors and do not reflect the official policy or position of any affiliated agency of the authors.

The authors declare that this is their own work submitted for publication.

\section{References}

Agnihotri, R., Dingus, R., Hu, M.Y. \& Krush, M.T., 2016, 'Social media: Influencing customer satisfaction in B2B sales', Industrial Marketing Management 53 , 172-180.

Ahmad Pozin, M., Mohd Nawi, M., Othuman Mydin, A., Mehdi Riazi, S. \& Imran, A., 2019, An ability of WhatsApp usage in Industrialised Building System (IBS) construction project, International Association of Online Engineering, Sintok, Kedah, Malaysia. viewed 19 November 2020, from https://www.learntechlib.org/p/208534/.

Alavi, M. \& Denford, J., 2011, 'Knowledge management: Process, practice and web 2.0', in M. Easterby-Smith Marjorie \& A. Lyles (eds.), Handbook of organizational learning and knowledge management, pp. 105-124, John Wiley \& Sons, Hoboken, NJ. https://doi.org/10.1002/9781119207245.ch6

Asur, S. \& Huberman, B.A., 2010 'Predicting the future with social media', in Proceedings of the 2010 IEEE/WIC/ACM International Conference on Web Intelligence and Intelligent Agent Technology-Volume 01, Washington, DC, USA, Intelligence and Intelligent Agent Technology-
31 August-02 September 2013, pp. 492-499.

Bala, M. \& Kumar, D., 2011, 'Supply chain performance attributes for the fast moving consumer goods industry', Journal of Transport and Supply Chain Management 5(1), 23-38. https://doi.org/10.4102/jtscm.v5i1.19 
Bellamy, K., Ostini, R., Martini, N. \& Kairuz, T., 2016, 'Seeking to understand: Using generic qualitative research to explore access to medicines and pharmacy services among resettled refugees', International Journal of Clinical Pharmacy 38(3), 671-675. https://doi.org/10.1007/s11096-016-0261-1

Ben-Daya, M., Hassini, E. \& Bahroun, Z., 2019, 'Internet of things and supply chain management: A literature review', International Journal of Production Research 57(15-16), 4719-4742. https://doi.org/10.1080/00207543.2017.1402140

Bharucha, J., 2018, 'Social media and young consumers behavior', International Journal of Supply Chain Management 7(6), 72-81.

Braun, V. \& Clarke, V., 2012, 'Thematic analysis', in H. Cooper, (eds.), APA handbook of research methods in psychology, American Psychology Association, Washington, DC.

Bronner, F. \& De Hoog, R., 2014, 'Social media and consumer choice', International Journal of Market Research 56(1), 51-71. https://doi.org/10.2501/IJMR-2013-053

Canada, J., 2019, 'Is reputational damage worse than a regulator's fine?' Network Security 2019(3), 11-12. https://doi.org/10.1016/S1353-4858(19)30035-2

Campie, P., 2015, 'The social media playbook for FMS', Buildings 109(9), 50-56.

Chae, B., 2015, 'Insights from hashtag \#supplychain and Twitter analytics: Considering Twitter and Twitter data for supply chain practice and research', International Journa of Production Economics 165, 247-259. https://doi.org/10.1016/j.ijpe.2014.12.037

Choudhury, M.M. \& Harrigan, P., 2014, 'CRM to social CRM: The integration of new technologies into customer relationship management', Journal of Strategic Marketing 22(2), 149-176.

Creswell, J.W., 2012, Educational research: Planning, conducting and evaluating quantitative and qualitative research, 4th edn., Pearson, Boston, MA.

Cui, R., Gallino, S., Moreno, A. \& Zhang, D.J., 2018, 'The operational value of social media information', Production and Operations Management 27(10), 1749-1769. media information', Production and Oper
https://doi.org/10.1111/poms.12707

Deans, P.C., 2011, 'The impact of social media on C-level roles', MIS Quarterly Executive 10(4), 6.

Diffley, S. \& McCole, P., 2019, 'The value of social networking sites in hotels', Qualitative Market Research: An International Journal 22(2), 114-132.

Elmusharaf, K., 2012, Qualitative sampling techniques, Department of Medical Sciences, University of Medical Sciences and Technology, Geneva.

Evans, D., McKee, J. \& Bratton, S., 2010, 'Social media and customer engagement', in D. Evans (eds.), Social media marketing: The next generation of business engagement, Technology Pub., Hoboken, N.J. pp. 3-21.

Flynn, B.B., Zhao, X., Huo, B. \& Yeung, J.H.Y., 2008, 'We've got the power! How customer power affects supply chain relationships', Business Horizons 51(3) 169-174. https://doi.org/10.1016/j.bushor.2008.01.009

Gouws, E. \& Motala, T., 2019, Quality of service delivered by alcoholic beverage suppliers to customers in the South African hospitality industry, viewed 12 May 2019, from https://www.ajhtl.com/uploads/7/1/6/3/7163688/article_8 vol_8_3_2019.pdf.

Govender, T., Niemann, W., Meyer, A. \& Kotze, T., 2018, 'Agile practices and supply chain resilience: A study of food and beverage manufacturers in South Africa' S.P. Van der Merwe \& J.A. Jordaan (eds.), International Business Conference Proceedings, Mauritius, 23-26 September 2018, pp. 1766-1775.

Guest, G., Bunce, A. \& Johnson, L., 2006, 'How many interviews are enough?: An experiment with data saturation and variability', Field Methods 18(1), 59-82. https://doi.org/10.1177/1525822X05279903

Gunarathne, P., Rui, H. \& Seidmann, A., 2017, 'Whose and what social media complaints have happier resolutions? Evidence from Twitter', Journal of Management Information Systems 34(2), 314-340. https://doi.org/10.1080/074 21222.2017.1334465

Gunarathne, P., Rui, H. \& Seidmann, A., 2018, 'When social media delivers customer service: Differential customer treatment in the airline industry', MIS Quarterly 42(2), 489-520. https://doi.org/10.25300/MISQ/2018/14290

Gussenhoven, C.J. \& Rabinowitz, D., 2014, Twitter's effect on share price movements of the Johannesburg Stock Exchange, viewed 12 June 2019, from http://hdl. handle.net/2263/41977.

Ismail, A.R., 2017, 'The influence of perceived social media marketing activities on brand loyalty', Asia Pacific Journal of Marketing and Logistics 29(1), 129-144. https://doi.org/10.1108/APJML-10-2015-0154

Kaplan, A.M. \& Haenlein, M., 2010, 'Users of the world, unite! The challenges and opportunities of social media', Business Horizons 53(1), 59-68. https://doi. org/10.1016/j.bushor.2009.09.003

Kapoor, K.K., Tamilmani, K., Rana, N.P., Patil, P., Dwivedi, Y.K. \& Nerur, S., 2018 , 'Advances in social media research: Past, present and future', Information Systems Frontiers 20, 531-558. https://doi.org/10.1007/s10796-017-9810-y

Kasemsap, K., 2018, 'Mastering Social Media in the Modern Business World', in Management Association, I. (eds.), Social media marketing: Breakthrough in research and practice, pp. 111-137, IGI Global, Hershey, PA. http:// doi:10.4018/978-1-5225-5637-4 ch007

Kietzmann, J.H., Hermkens, K., McCarthy, I.P. \& Silvestre, B.S., 2011, 'Social media? Get serious! Understanding the functional building blocks of social media', Business Horizons 54(3), 241-251. https://doi.org/10.1016/j.bushor.2011.01.005

Lietz, C.A. \& Zayas, L.E., 2010, ‘Evaluating qualitative research for social work practitioners', Advances in Social Work 11(2), 188-202. https://doi org/10.18060/589

Manders, J.H., Caniëls, M.C. \& Paul, W.T., 2016, 'Exploring supply chain flexibility in a FMCG food supply chain', Journal of Purchasing and Supply Management 22(3), 181-195. https://doi.org/10.1016/j.pursup.2016.06.001
Markova, S. \& Petkovska-Mircevska, T., 2013, 'Social media and supply chain', Amfiteatru Economic 15(33), 89-102.

Mason, M., 2010, 'Sample size and saturation in PhD studies using qualitative interviews', Forum qualitative sozialforschung/forum: Qualitative social research 11(3). http://doi.org/10.17169/fqs-11.3.1428

Meixner, O., Haas, R., Moosbrugger, H. \& Magdits, P., 2013, 'Interaction with customers: The application of social media within the Austrian supply chain for food and beverages', International Journal on Food System Dynamics 4(1), 26-37.

Meyer, A., Niemann, W., Uys, G. \& Beetge, D., 2019, 'An exploration of supply chain risk management in the South African third-party logistics industry', Acto Commercii 19(1), 1-13.

Milne, J. \& Oberle, K., 2005, 'Enhancing rigor in qualitative description', Journa of Wound Ostomy \& Continence Nursing 32(6), 413-420. https://doi. org/10.1097/00152192-200511000-00014

Mvubu, M. \& Naude, M.J., 2016, 'Green supply chain management constraints in the South African fast-moving consumer goods industry: A case study', Journal of Contemporary Management 13(1), 271-297.

Newton, N., 2010, 'The use of semi-structured interviews in qualitative research: Strengths and weaknesses', Exploring Qualitative Methods 1(1), 1-11.

Ngai, E.W., Tao, S.S. \& Moon, K.K., 2015, 'Social media research: Theories, constructs, and conceptual frameworks', International Journal of Information Management 35(1), 33-44. https://doi.org/10.1016/j.ijinfomgt.2014.09.004

Nguyen, B. \& Mutum, D.S., 2012, 'A review of customer relationship management: Successes, advances, pitfalls and futures', Business Process Management Journal 8(3), 400-419. https://doi.org/10.1108/14637151211232614

Nielsen, 2018, South African online FMCG sector shows massive growth potential, viewed 16 November 2019, from https://www.nielsen.com/za/en/pressreleases/2018/south-african-online-fmcg-sector-shows-massive-growthpotential/.

O'Leary, D.E., 2011, 'The use of social media in the supply chain: Survey and extentions', Intelligent Systems in Accounting, Finance \& Management 18(2/3), 121-144. https://doi.org/10.1002/isaf.327

O'Leary, D.E., 2016, 'KPMG knowledge management and the next phase: Using enterprise social media', Journal of Emerging Technologies in Accounting 13(2), 215-230.

Orji, I.J., Kusi-Sarpong, S. \& Gupta, H., 2020, 'The critical success factors of using social media for supply chain social sustainability in the freight logistics industry', International Journal of Production Research 58(5), 1522-1539.

Payne, A. \& Frow, P., 2005, 'A strategic framework for customer relationship management', Journal of Marketing 69(4), 167-176.

Pearson, M., 2015, 'After-sales service: The forgotten supply chain', Logistics Management 54(3), 20-21.

Percy, W.H., Kostere, K. \& Kostere, S., 2015, 'Generic qualitative research in psychology', The Qualitative Report 20(2), 76-85.

Poba-Nzaou, P., Uwizeyemungu, S. \& Clarke, C., 2018, 'Patterns underlying required HR and IT competencies: A content and cluster analysis of advertisements of HR manager positions', The International Journal of Human Resource Management 31(16), 1-24. https://doi.org/10.1080/09585192.2018.1424019

Polit, D. \& Beck, C., 2012, 'Nursing research: Generating and assessing evidence for nursing practice', Ethics 23(2), 510-540.

Ramanathan, U., Subramanian, N. \& Parrott, G., 2017, 'Role of social media in retail network operations and marketing to enhance customer satisfaction', International Journal of Operations \& Production Management 37(1), 105-123. https://doi.org/10.1108/IJOPM-03-2015-0153

Rapp, A., Beitelspacher, L.S., Grewal, D. \& Hughes, D.E., 2013, 'Understanding social media effects across seller, retailer, and consumer interactions', Journal of the Academy of Marketing Science 41(5), 547-566. https://doi.org/10.1007/s11747013-0326-9

Ripl Inc, 2017, U.S. small business social media marketing research study results - Q2 2017, Ripl Inc., Bellevue, viewed 31 March 2020, from http://ww1.prweb.com/prfiles/2017/ 06/26/14461982/2017_US-Small_Business_Social_Media_Trends_Ripl.pdf.

Robinson, O.C., 2014, 'Sampling in interview-based qualitative research: A theoretical and practical guide', Qualitative Research in Psychology 11(1), 25-41. https://doi. org/10.1080/14780887.2013.801543

Rodrigues, S.V., 2013, 'A comparison of FMCG logistics operations in the UK and South Africa', European Business Review 25(4), 351. https://doi.org/10.1108/EBR-022013-0014

Shenton, A.K., 2004, 'Strategies for ensuring trustworthiness in qualitative research projects', Education for Information 22(2), 63-75. https://doi.org/10.3233/EFI2004-22201

Shirky, C., 2011, 'The political power of social media: Technology, the public sphere, and political change', Foreign Affairs $90(1), 28-41$, viewed 19 November 2020 from http://www.jstor.org/stable/25800379.

Singh, A., Shukla, N. \& Mishra, N., 2018, 'Social media data analytics to improve supply chain management in food industries', Transportation Research Part E: Logistics and Transportation Review 114, 398-415. https://doi.org/10.1016/j. tre.2017.05.008

Swain, A. \& Cao, Q., 2013, 'Exploring the impact of social media on supply chain performance: A sentiment analysis', In The Proceedings of 44th Annual Meeting, Decision Sciences Institute, 16-19, November, Baltimore, Maryland

Swan, M., 2017, 'Anticipating the economic benefits of blockchain', Technology Innovation Management Review 7(10), 6-13. https://doi.org/10.22215/ timreview/1109 
Syed, D. \& Siddiqui, D.A., 2019, 'Impact of outsourcing and other factors on logistics performance in FMCG sector of Pakistan', Asian Journal of Science and Technology 10(2), 9386-9390.

Taylor, S.J., Bogdan, R. \& DeVault, M., 2015, Introduction to qualitative research methods: A guidebook and resource, John Wiley \& Sons. Hoboken, NJ.

Triantafillidou, A. \& Siomkos, G., 2018, 'The impact of Facebook experience on consumers 'behavioral brand engagement', Journal of Research in Interactive Marketing 12, 164-192. https://doi.org/10.1108/JRIM-03-2017-0016

Vaismoradi, M., Jones, J., Turunen, H. \& Snelgrove, S., 2016, 'Theme development in qualitative content analysis and thematic analysis', Journal of Nursing Education and Practice 6(5), 100-110. https://doi.org/10.5430/jnep.v6n5p100

Valentini, C., 2015, 'Is using social media "good" for the public relations profession? A critical reflection', Public Relations Review 41(2), 170-177. https://doi. org/10.1016/j.pubrev.2014.11.009

Vogt, S., Förster, B. \& Kabst, R., 2014, 'Social media and e-participation: challenges Administration in the Digital Age (IJPADA) 1(3), International Journal of Public ijpada.2014070105
Wang, J.-C., Wang, Y.-Y. \& Che, T., 2019, 'Information sharing and the impact of shutdown policy in a supply chain with market disruption risk in the social media era', Information \& Management 56(2), 280-293. https://doi.org/10.1016/j. im.2018.09.005

Whiting, A. \& Williams, D., 2013, 'Why people use social media: A uses and gratifications approach', Qualitative Market Research: An International Journa 16(4), 362-369. https://doi.org/10.1108/QMR-06-2013-0041

Whiting, A., Williams, D.L. \& Hair, J., 2019, 'Praise or revenge: Why do consumers post about organizations on social media', Qualitative Market Research: An International Journal 22(2), 133-160. https://doi.org/10.1108/QMR-06-20170101

Wong, D.T. \& Ngai, E.W., 2019, 'Critical review of supply chain innovation research (1999-2016)', Industrial Marketing Management 82, 158-187. https://doi. org/10.1016/j.indmarman.2019.01.017

Zadeh, A.H., Zolfagharian, M. \& Hofacker, C.F., 2019, 'Customer-customer value cocreation in social media: conceptualization and antecedents', Journal of Strategic Marketing 27(4), 283-302. 